\title{
Series of Discrimination: Exploring Discrimination among Children
}

\author{
Patricia Tanjung \\ English Department, Faculty of Letters, Petra Christian University, Siwalankerto 121-131, Surabaya 60236, \\ Indonesia. \\ E-mail: m11416012@john.petra.ac.id
}

\begin{abstract}
This series of children's literature focuses on discrimination among children based on their race, sex, disability, physical attractiveness, and social class. The goal is to find the ways children discriminate against their friends and also the ways they cope with discrimination. To do so, this creative thesis uses the concept of prejudice and discrimination and also the theory of Coping. From the series, it is shown that children can verbally, behaviorally, and relationally discriminate against their friends and that children can use problemfocused coping to cope with discrimination. Therefore, by understanding ways discrimination manifests itself and knowing how to cope with discrimination, children can detect discrimination and learn to cope with it.
\end{abstract}

Keywords: Discrimination, Picture Books, Children's literature, Realistic fiction

\section{INTRODUCTION}

I decided to write a picture book of children's literature as my creative thesis since the sweetest memory of my childhood is the time when my parents read storybooks for me. Besides, according to Ikatan Penerbit Indonesia (IKAPI) 2015 research, among 8,510 million copies of sold books in 2014, children's books had the highest market share with $22.64 \%$ ("Riset," 2015). This data shows that there is a good possibility that the best way to cultivate Indonesian children about social issues is through children's books since children's books have the highest demand in Indonesia. As Martha Crippen from the Publication of Luther College \& Decorah Public Library has stated, children literature helps children develop their emotional intelligence, creativity, and social skills and provide children with opportunities to respond to literature and appreciate their cultural heritage as well as others' (Crippen, 2012). That being said, I would like to dedicate my creative work to the younger generations so they can develop their social skills and appreciate their own culture.

The fact that children's books are powerful to teach children about difficult topics in a fun way, encourages me to explore the issue of discrimination among children. I would like to focus on the ways children are discriminated against and the ways children cope up with discrimination. To discriminate against someone, according to Compasito, a manual on human rights education for children, "is to exclude that person from the full enjoyment of their political, civic, economic, social or cultural rights and freedoms" (Flowers, 2009, p. 216). This creative thesis focuses on children's race, physical attractiveness, sex, disability, and social class as the bases of discrimination because Convention on the Rights of the Child (CRC)'s article 2 explains that discrimination can also be based on the child's or his or her parent's or legal guardian's race, sex, disability, or other statuses, which allows many other causes of discrimination such as social class (Flowers, 2009, p. 216). Furthermore, race, social class, disability, and sex, are the most common bases of discrimination in Indonesia (World Bank as cited in Program Peduli, 2016, p. 13). In addition, this creative thesis also includes physical attractiveness as one of the bases of discrimination since Rennels and Langlois, 
professors of psychology, conducted a research and found that children showed attractiveness biases during middle childhood which include positive attributions, such as well-behaved, smart, and helpful, toward attractive individuals and negative attributions, such as stupid, naughty, mean, and lazy, toward unattractive individuals and include preferences for attractive peers (Rennels \& Langlois, 2014, p. 12-14).

The reason why discrimination is an important issue to be understood is that discrimination has severe negative effects on children's emotional and mental health. It can lead to emotional and mental harm and increase aggression and delinquency for children (Dulin-Keita, et al., 2011, p. 3). That is why it is better to educate young people about discrimination as early as possible so that discrimination can be prevented, and in the long run, cases of discrimination can be decreased.

This creative work is focusing mainly on children from the age of six to eight. The reason is that first, when children start school at age five to seven years, minority-group children may begin to directly experience prejudice and discrimination from their majority-group peers and as they grow older, minority-group children become increasingly aware of societal racism and discrimination (Kite \& Whitley, 2016, p. 270). In one longitudinal study, African Americans experience institutional and individual racism during elementary school (Dulin-Keita, et al., 2011, p. 3). There is ninety-two percent of black children aged ten or younger, experienced racial discrimination while twelve percent of Puerto Rican children aged seven to nine living on the mainland of the United States are attributed discriminatory events to their ethnicity (Dulin-Keita, et al., 2011, p. 3). Although the study was conducted in the United States, discrimination can happen anywhere such as Indonesia since Indonesia has a lot of ethnicities that live in so many islands. Second, in Writing Picture Books, picture books are for two to eight years old children (Paul, 2018, p. 32). Lastly, although children aged eight and below can enjoy picture books discussing discrimination, the word choice used for the creative work is suitable for children aged six to eight years old. Given those reasons, this creative work is for children who have understood about prejudice and discrimination, and who might enjoy picture books and the word choice.

Unfortunately, there are children who do not get any syllabus or textbook about discrimination, or discussion about discrimination in their schools. Worse, they could learn about discrimination by being the victims of it. However, they do not have to be the victims of discrimination to know and understand about it. There are lots of ways for parents to introduce discrimination to their children which one of them is using exciting children's literature. Children's books not only can engage young readers to understand discrimination, but it also can be a reading homework from school to enhance their reading ability or as something to read in their leisure time.

While the format is a picture book, the genre of this creative work is realistic fiction, a subgenre of fiction. As stated in Children's Books in Children's Hands, the definition of realistic fiction is "fictional stories that might have happened" (Temple, Martinez, \& Yokota, 2018, p.26). Since the realistic fiction genre can reveal the character's social settings, this genre is the most suitable genre for the issue of discrimination that needs social settings such as race and social class. Furthermore, by using realistic fiction, I can highlight a social issue that can only happen in human which based on realistic traits, such as race, sex, and personality to make children understand discrimination as a problem that can occur in their lives. Another reason why I use realistic fiction is that there are numerous well-known picture books using realistic fiction that can raise difficult social issues very well that young readers can comprehend them and enjoy the picture books. I hope my creative work can too explore discrimination in an exciting and fun way through the realistic fiction genre. 
Tanjung: Series of Discrimination:

Exploring Discrimination among Children

This creative work will consist of five stories dealing with discrimination among children. The victims are minority children, and they are discriminated based on their race, physical attractiveness, disability, sex, and social class. Being minorities and different among others can cause the characters to face discrimination in many ways. In the end, the characters succeed to cope with discrimination.

This creative work is suitable for children aged six to eight. Through this creative work, children can detect discrimination and learn how to cope with discrimination. They may learn about discrimination while enjoying the story as leisure. In addition, it is also important for parents, legal guidance, or teachers to be more aware of discrimination. Furthermore, since there is a probability for parents to read it for them or at least accompany their children. This may bring parents and children relationship closer, discussion about discrimination, and promote literacy for the younger generations.

In order to show that children discriminate against others using physical, verbal, and relational bullying, there is Psychology of Prejudice and Discrimination by Mary E. Kite and Bernard E. Whitley. The other one is Compasito, a manual on human rights education for children, by Nancy Flowers. Moreover, in order to show that children cope with discrimination using problem-focused coping, I am using Lazarus and Folkman's concept of coping from The Oxford Handbook of Health Psychology by Howard S. Friedman and Stress and Coping with Discrimination and Stigmatization by Sophie Berjot and Nicolas Gillet.

This creative thesis uses the secondary research method. I found journals, theories, and data about discrimination that have primary research done and written by experts in psychology, sociology, and children's development. Those pieces of information can make the characters and the plots more make sense and valid. Furthermore, I read some realistic fiction picture books such as Oliver Button Is a Sissy by Tomie dePaola, Amazing Grace by Mary Hoffman, and The Name Jar by Yangsook Choi to gather information to understand the realistic fiction genre, even more, the way realistic fiction influence the readers, and later on, use them to make the creative work.

In addition, although they are not mentioned in the creative works, there are real references I use to help me make this creative work. There are children whom I know in my life as the characters' references for making the characters' personality and physical attributions. I also use real elementary schools in Surabaya as the social setting references to guide me through the plot. By using concepts that have been conducted several times and used to generate new theories, reading realistic fiction picture books, and using real-life references, I hope this creative thesis can be feasible and credible.

\section{OUTLINE OF CREATIVE WORK}

\subsubsection{Theme}

The subject matter of this creative work is discrimination among children. The theme for this creative work is children can relationally, verbally, and behaviorally discriminate against their friends, and coping with discrimination by actively focusing on solving the problem is important for children to be free from the negative impacts of discrimination. There are lots of ways for children 
to discriminate against their friends, but those ways can be grouped into relational, verbal, and behavioral. As victims of discrimination, children can get negative effects of discrimination that can harm their feelings and energy to do well in school. There are also lots of ways to deal with discrimination but instead of running from reality or avoiding it, the victims should focus on how to solve their problems with discrimination as it can provoke their creativity and endurance, as well as free them from the negative effects of discrimination. By knowing the ways discrimination manifest itself and how harmful it is for them, readers can learn healthy ways to cope with discrimination.

\subsubsection{Plot}

This creative work consists of five stories, so there are five plots for each story.

\subsubsection{Olivia Ong, the Girl with Slanted Eyes}

Olivia was the only Chinese student in her school. Her friends discriminate against her by intimidating her, mimicking her, and calling names. Feeling uncomfortable, she asks her brother hoping his advice can stop her friends from discriminating against her. She stays away from her friends and wants to quit school. She realizes that she cannot change her slanted eyes or her appearance, but she can change Uton's prejudice towards her. Therefore, when Uton mocks her as a stingy person, she wants to help him while proving that she is not stingy. In the end, she is no longer discriminated against, and they become friends.

\subsubsection{Gorilla in the Class}

Joey tries to make friends, but no one wants to befriend her because she is ugly. Since Joey is ugly for her classmates, they call her gorilla and discriminate against her by not allowing her to join their activities. Knowing her physical features hinder her from having friends, she tries to go on a diet and change her appearance based on her classmates' beauty standards and fails. She hates herself and thinks that there is nothing she can do. However, after realizing that she cannot change her appearance, she wants to change her classmates' way of thinking about her. She tries to prove to them that although she is ugly, she is smart, kind, and helpful. In the end, Joey gains some friends.

\subsubsection{Lukas the One-Legged Boy}

After a car accident, Lukas has to amputate his leg. Since he has only one leg, his friends avoid him, and he is lonely. It makes him do poorly at school. His sister knows what happened and tells Lukas to prove to his friends that he is not useless. He realizes that he bothers his teachers and friends. After being rejected by the committee of the talent show from signing up, he stands up for himself. In the end, he joins the talent show by singing to prove to his friends that he can still do something. After he finishes performing, his friends like it. Since then, he has gained some friends.

\subsubsection{Ajeng the Class Captain}

As the first grade begins, Ajeng becomes the class captain. Roy and Fano do not think that a girl can be a good leader, so they tell her that she cannot be a good class captain. They discriminate against her. She was sad and anxious. She tries to answer them back that a girl can be a good class captain and prove to them that she can be a good class captain by doing her responsibility well.

However, Roy and Fano do not stop discriminating against her. One day, Ajeng finds out that Roy is also discriminated against by his friends. Knowing how that feels, Ajeng decides to help Roy. 
Tanjung: Series of Discrimination:

Exploring Discrimination among Children

After that incident, Roy admits that he should not discriminate against others and a girl like Ajeng is a good class captain. They become friends.

\subsubsection{Wira}

Wira's classmates know that he comes from a poor family, so they discriminate against him by rejecting and insulting him. He thinks that if he can fight back, they will stop discriminating against him, instead, things get worse. He develops hatred towards her classmates. After realizing that he should not get square, he stops fighting back. When Victor's lunch box is missing, his classmates accuse him. He didn't steal it and tried his best not to get square.

\subsubsection{Characters}

\section{Main characters:}

\section{Olivia Ong}

Age: 7 years old

Olivia Ong is a Chinese Indonesian. She cares about her appearance. She likes to wear a dress, hat, and ribbons. She asks her mother every day to have her one or two pigtails with ribbons. She is an active person. She has white skin, slanted eyes, and chubby cheeks. She has short brownish black hair and average body size for her age. She is kind and delicate. She does not like confrontation. She feels really uncomfortable when her friends insult her for being a stingy Chinese. Instead of quarreling, she prefers to walk off.

Joey

Age: 6 years old

Joey's father has gigantic body features and has brown skin color, whereas her mother has black curly hair. These allow her to have round body features, dark skin color, and black curly hair. Since she is also taller than children around her age, she is considered humongous for her friends. She used to eat a big portion meal since her parents also used to eat a lot. She is an only child and since her parents are rarely at home, she is only accompanied by her housekeeper. Sometimes she is lonely, but she is glad that she has her books to read and puzzles to play with. She is a soft person who is afraid of loud noise. She cannot stand being shouted at and bullied since she is considered ugly by her friends. Therefore, she tries to follow her friends' beauty standards by changing herself so that her friends will stop bullying her, instead accept her to be their friend.

Lukas

Age: 8 years old

Lukas has a supportive older sister, and they are kind to one another. He is a healthy thin boy who is very active. He does not really care about his appearance. He is adventurous and brave. He used to be an outgoing person who likes to spend his time playing with his friends. However, his friends have discriminated against him by avoiding and excluding him from hanging out since he 
only has one leg. As an outgoing person who likes to hang out and to have friends, he tries to use his creativity to have friends back.

Ajeng

Age: 7 years old

Ajeng is a girly thin girl with long black hair and bangs. She is a neat person who likes to tidy things up. She is responsible and orderly. She likes to read and plays with younger children. She is the class captain in her class. She is not really confident, especially when her friends discriminate against her. Tired of hearing her friends mocking and belittling her, her persistence wants to prove to her friend that a girl like her can be a good class captain.

Wira

Age: 7 years old

Wira is a skinny boy who tends to eat a little. He has brown skin color and shabby clothes. He does not really care about his appearance. Although he comes from a poor family, they love each other very much. He used to live in a small city. However, since his father died, his mother decided to move to a big city where Wira's uncle would finance his school fee. While his mother has to work, as the oldest son, he tends to be in charge. He learns from her mother to be creative and tenacious. He is a quiet person who does not like to complain. He is diligent, obedient, and sometimes stubborn. However, when he goes to a new school where he becomes a minority, he learns that he is poor. The fact that he is mistreated by his friends allows his audacity to fight back. Although it fails, his grit makes him patient towards his friends.

\section{Supporting characters:}

Uton

Age: 7 years old

Uton likes to tease her friends. He is outgoing and talkative. He also has a father who works with a Chinese boss. Sometimes he heard that his father's boss is stingy and evil. He is a hardworking child who respects his parents and older people. Olivia Ong is his first Chinese classmate he ever has.

\section{David Ong}

Age: 14 years old

He is Olivia Ong's older brother. He is kind and always willing to help. He is smart and people tend to depend on him.

Angela

Age: 7 years old 
Tanjung: Series of Discrimination:

Exploring Discrimination among Children

Angela does not have any siblings. She is an active person who likes to hang out with her friends. Her parents are rarely at home. She has lots of private lessons and gadgets to keep her occupied from being lonely.

Jen

Age: 13 years old

She is Lukas's older sister who likes music. She is good at playing the piano and helping others. She likes children, and children like her too. She is responsible and friendly.

Roy

Age: 6 years old

Roy is a second child who only has a father and an older brother in his house. He does not like his older brother because his big brother likes to tease him. He is brave and domineering. He likes to prank others and make fun of his friends.

Ms. Sari

Age: 43 years old

Ms. Sari is Ajeng's homerun teacher. She is smart, kind, and observant. She is good at looking at someone's potential and helping her or him to meet her expectations.

Victor

Age: 6 years old

Victor has twin little sisters. He does not really get his parents' attention since they are busy with the twins. Therefore, sometimes he is lonely. He lives in a big house in an upper-class residence. His parents do not treat his housemaid well, sometimes they scold her. They have changed several housemaids, and some of them are because they have stolen something from Victor's family. He has never been to an orphanage, and he is not used to meeting poor people like Lukas.

\subsection{Conflict}

In the creative work, there are two types of conflicts that happen. The first one is man vs man which "is probably the most common form of external conflict and is also known as interpersonal conflict" (Cascio, 2020). This mode lies at the heart of all dramatic arts and places the struggle directly between the protagonist and the antagonist. In a man vs. man conflict, the protagonist wants something, and the antagonist obstructs the protagonist from getting what he wants (Cascio, 2020). In the creative work, the protagonists deal with discrimination against their friends. This can be shown by the main characters that are discriminated against because of their unique characteristics.

Another conflict that the main characters deal with is man vs self. Man vs. self is an internal conflict which takes place within the mind of the main character and often involves the character 
making a decision between right and wrong, or other mixed emotions (Cascio, 2020). In other words, this conflict may entail a struggle to discern what the moral or the right choice is. Their struggles happen within them, and it drives their development as a character. Since the main characters are discriminated against, they have internal struggles affecting their actions, emotions, and solution to their problems.

\section{CONCLUSION}

Through this project, I learned how difficult it is to create a series of picture books that is simple but contains a deep issue, yet interesting for the audience. Not only is it difficult to apply the theories to the creative work, but making sure they are understandable to young readers is also difficult. In the process, I learned lots of things about making a creative thesis. First of all, it is important to research, especially because the stories are about children while I am no longer one. Doing research allows me to make sure that the characters' actions, personalities, backgrounds, and plots are believable and in line with realistic genre fiction. Guidelines such as Ann Whitford Paul's Writing Picture Books also help me to understand how to deliver a social issue to be understood by children. Furthermore, reading English and Indonesian picture books as a reference is essential for me in making this creative work. Whether their similarity in issue, genre, theme, or background with this creative thesis, they give broader options of style and ways to deliver the story. Those picture books also taught me to be concise and give examples on how to apply the guideline of picture books. Secondly, I learned to make the plot as simple as possible since the target audience of this creative work is elementary children. This means I had to limit the word choice for children to be understandable, yet fun at the same time. Also, it means I had to cut some events, descriptions, and actions since there is page limitation. It is hard to maintain simplicity, so the audience will easily understand what the series is about, especially when they are not used to reading books at an early age. Thirdly, making five plots for this creative work is not easy. Since the five stories are under one big issue which is discrimination. I had to choose different ways children discriminate, solutions, backgrounds, characters' personalities, and endings to one another to make them diverse and interesting. Lastly, there were times that I didn't know what to do, but being open to my advisor helped me to accomplish this creative thesis. The consultation with the advisor and her inputs helped and encouraged me to finish the creative thesis as fast and good as I could.

\section{REFERENCES}

Berjot, S., \& Gillet, N. (2011). Stress and coping with discrimination and stigmatization. Frontiers in Psychology, 2. doi:10.3389/fpsyg.2011.00033

Cascio, C. (2020). Types of conflict that can be found in a narrative. Retrieved from https://education.seattlepi.com/types-conflict-can-found-narrative-3739.html

Crippen, M. (2012). The value of children's literature. Oneota Reading Journal. Retrieved from https://www.luther.edu/oneota-reading-journal/archive/2012/the-value-of-childrensliterature/

Dulin-Keita, A., Hannon Iii, L., Fernandez, J. R., \& Cockerham, W. C. (2011). The defining moment: Children's conceptualization of race and experiences with racial discrimination. Ethnic and Racial Studies, 34(4), 662-682.

doi:10.1080/01419870.2011.535906

Flowers, N. (2009). Compasito: Manual on human rights education for children (2nd ed.). Retrieved from http://www.eycb.coe.int/compasito/pdf/Compasito\%20EN.pdf 
Tanjung: Series of Discrimination:

Exploring Discrimination among Children

Friedman, H. S. (2013). The Oxford handbook of health psychology.

Ikatan Penerbit Indonesia (IKAPI). (2015). Riset. Retrieved from https://www.ikapi.org/riset/

Kite, M. E., \& Bernard E. Whitley, J. (2016). The experience of discrimination. In Psychology of prejudice and discrimination: $3 r d$ edition (3rd ed., pp. 16, 430-433).

Paul, A. W. (2018). Writing picture books revised and expanded edition: A hands-on guide from story creation to publication. London, England: Penguin.

Program Peduli. (2016). Understanding social exclusion in Indonesia. Retrieved from The Asia Fondation website: https://asiafoundation.org/wp-content/uploads/2016/10/UnderstandingSocial-Exclusion-in-Indonesia.pdf

Rennels, J. L., \& Langlois, J. H. (2014). Children's attractiveness, gender, and race biases: A comparison of their strength and generality. Child Development, 85(4), 1401-1418. doi:10.1111/cdev.12226

Temple, C. A., Martinez, M. A., \& Yokota, J. (2018). Children's books in children's hands: A brief introduction to their literature (6th ed.). Retrieved from

https://www.pearsonhighered.com/assets/preface/0/1/3/4/0134798686.pdf 